\title{
Mechano-stimulated modifications in the chloroplast antioxidant system and proteome changes are associated with cold response in wheat
}

\author{
Xiangnan $\mathrm{Li}^{1,2}$, Chenglong Hao ${ }^{1}$, Jianwen Zhong ${ }^{1}$, Fulai Liu², Jian Cai ${ }^{1}$, Xiao Wang ${ }^{1}$, Qin Zhou ${ }^{1 *}$, Tingbo Dai ${ }^{1}$, \\ Weixing $\mathrm{CaO}^{1}$ and Dong Jiang ${ }^{1 *}$
}

\begin{abstract}
Background: Mechanical wounding can cause morphological and developmental changes in plants, which may affect the responses to abiotic stresses. However, the mechano-stimulation triggered regulation network remains elusive. Here, the mechano-stimulation was applied at two different times during the growth period of wheat before exposing the plants to cold stress $\left(5.6^{\circ} \mathrm{C}\right.$ lower temperature than the ambient temperature, viz., $\left.5.0^{\circ} \mathrm{C}\right)$ at the jointing stage.

Results: Results showed that mechano-stimulation at the Zadoks growth stage 26 activated the antioxidant system, and substantially, maintained the homeostasis of reactive oxygen species. In turn, the stimulation improved the electron transport and photosynthetic rate of wheat plants exposed to cold stress at the jointing stage. Proteomic and transcriptional analyses revealed that the oxidative stress defense, ATP synthesis, and photosynthesis-related proteins and genes were similarly modulated by mechano-stimulation and the cold stress.

Conclusions: It was concluded that mechano-stimulated modifications of the chloroplast antioxidant system and proteome changes are related to cold tolerance in wheat. The findings might provide deeper insights into roles of reactive oxygen species in mechano-stimulated cold tolerance of photosynthetic apparatus, and be helpful to explore novel approaches to mitigate the impacts of low temperature occurring at critical developmental stages.
\end{abstract}

Keywords: Mechano-stimulation, Cold, Reactive oxygen species, Chloroplast, Wheat

\section{Background}

Chilling temperature significantly affects the early growth of winter wheat plants causing considerable reduction of grain yield and is one of the major factors limiting growth and productivity of crops [1]. Cold induced photosynthesis inhibition results in a complex array of reactive oxygen species (ROS) generation, especially in chloroplasts [2]. Over-accumulation of ROS may cause rigidification and leakage of the cell membrane, and destabilization of protein complexes [1]. Recent proteomic studies have revealed differential expression of proteins in wheat exposed

\footnotetext{
*Correspondence: qinzhou@njau.edu.cn; jiangd@njau.edu.cn

${ }^{1}$ National Engineering and Technology Center for Information Agriculture / Key Laboratory of Crop Physiology and Ecology in Southern China, Ministry of Agriculture, Nanjing Agricultural University, Nanjing 210095, China Full list of author information is available at the end of the article
}

to cold stress [3, 4]. Among the down-regulated proteins due to cold stress, some key enzymes involved in Krebs cycle (isocitrate dehydrogenase, malate dehydrogenase) have been identified, together with many photosynthesisrelated proteins (e.g. oxygen-evolving complex proteins, ATP synthase subunits, ferredoxin NADPH oxidoreductase, and some Calvin cycle enzymes) [3]. Proteomic analysis of spring freezing stress responsive proteins in leaves revealed an increased accumulation of stress defense proteins, including LEA-related $\mathrm{COR}$ protein, $\mathrm{Cu} / \mathrm{Zn}$ superoxide dismutase, and ascorbate peroxidases, which may play crucial roles in enhancing tolerance to spring freeze stress in bread wheat [4]. In addition, proteomic analysis of wheat in response to prolonged cold stress showed reinforcement in expressions of enzymes involving in 
ascorbate recycling (dehydroascorbate reductase, ascorbate peroxidase) and involving in tetrapyrrole resynthesis (glutamate semialdehyde aminomutase) [3].

Mechanical wounding can be caused by surrounding environmental factors, such as wind, rainstorms, and herbivores, and it has broad impacts on plants, including changes in morphogenetic characteristics, membrane potential [5], ROS, hormone signaling and gene expression [6]. Several alterations induced by mechanical wounding can allow plants to resist and acclimate to environmental stresses [6]. As previously observed in maize, bean, and rice, denser but smaller stomata in mechanically stimulated leaves could help plants to control transpirational water loss, thereby avoiding drought stress [7]. Mechano-stimulation was reported to increase cold tolerance in beans, tomato, and maize through maintenance of higher Photosystem II (PSII) efficiency and accumulation of higher levels of soluble sugars [8]. It was also suggested that similar defense mechanisms are operated in cold acclimation and mechanostimulation, resulting in similar morphological and developmental changes [8]. Recently, analysis of transcript profiles indicated various defense response genes were induced by mechano-stimulation, and were related to cold stress response, including general stress response (GSR), rapid stress response (RSR), and rapid wound response (RWR) [9]. In addition, it has been proposed that mechanical disruption of the cell wall may induce stress signaling [10]. Cold stress is perceived by the plant through detection of changes in membrane fluidity and protein conformation. Secondary messengers such as $\mathrm{Ca}^{2+}$ and $\mathrm{ROS}$ are implicated in the initial signaling cascades in response to cold stress [1].

Many studies reported changes in ROS levels following mechano-stimulation [11, 12]. For instance, mechanostimulation induced a significant increase in ROS levels in Mesembryanthemum crystallinum leaves [12]. Furthermore, proteomic studies have shown that plants transiently produce superoxide and $\mathrm{H}_{2} \mathrm{O}_{2}$, which might play critical roles in signal transduction during early wound response [13]. Mechano-stimulation induced increased expression of cytosolic $\mathrm{H}_{2} \mathrm{O}_{2}$-detoxifying enzyme, ascorbate peroxidase 2 (APX2) [14]. This increase in APX2 was independent of other mechanical wounding signals such as jasmonic acid (JA) or abscisic acid (ABA) [15]. It has also been suggested that NADPH-dependent $\mathrm{H}_{2} \mathrm{O}_{2}$ signals contribute to the activation of specific mechano-stimulated signals which are not activated by the JA or ABA [15]. The cellular steady-state level of ROS is tightly regulated by a complex network involving $\mathrm{Ca}^{2+}$, protein phosphorylation, and ROS-scavenging/producing enzymes during wound response [15]. In addition, mechanical wounding has been found to induce a burst of superoxide and apoplastic peroxidase with both oxidative and peroxidative activities $[15,16]$.

In this study, mechano-stimulation was applied to two contrasting winter wheat cultivars that differed in cold tolerance at different growth stages in order to investigate the effects of mechano-stimulation on the performance of the chloroplastic antioxidant system and changes of the proteome under late spring low temperature stress. The results obtained in this study may provide deeper insights into the roles of mechano-stimulated modifications within chloroplast antioxidant systems and proteome in cold tolerance in wheat. This information will be helpful for exploring novel approaches to mitigate the impacts of low temperatures which occur during critical developmental stages in wheat plants.

\section{Methods}

\section{Plant materials}

This experiment was carried out at Lianyungang Experimental Station of Nanjing Agricultural University $\left(119^{\circ}\right.$ $32^{\prime} \mathrm{E}, 34^{\circ} 30^{\prime} \mathrm{N}$ ) during the wheat growing season in 2011-2012. The soil is a clay, contains $11.4 \mathrm{~g} \mathrm{~kg}^{-1}$ organic matter, $1.1 \mathrm{~g} \mathrm{~kg}^{-1}$ total $\mathrm{N}, 79.8 \mathrm{mg} \mathrm{kg}^{-1}$ available $\mathrm{N}, 32.4 \mathrm{mg} \mathrm{kg}^{-1}$ Olsen-P, and $132.4 \mathrm{mg} \mathrm{kg}^{-1}$ available $\mathrm{K}$. Before sowing, $120 \mathrm{~kg} \mathrm{~N} h a^{-1}, 60 \mathrm{~kg} \mathrm{P}_{2} \mathrm{O}_{5} \mathrm{ha}^{-1}$ and $120 \mathrm{~kg} \mathrm{~K}_{2} \mathrm{O} \mathrm{ha}{ }^{-1}$ were applied as basal fertilizer and a further $120 \mathrm{~kg} \mathrm{~N} \mathrm{ha}^{-1}$ was used as a topdressing after jointing to avoid the potential impacts on stress treatments. Two winter wheat cultivars differing in cold tolerance but having close genetic backgrounds (Jimai 17 displays similar morphology and is related with Yannong 19 in pedigree), Yannong19 (YN19, cold tolerant) and Lianmai6 (LM6, cold susceptible, parents: YN19// Jimai 17/Zheng9023) were used in this experiment. The sowing date was 14 October 2011, with a seedling density of $160 \mathrm{~m}^{-2}$ and a row space of $0.25 \mathrm{~m}$. The jointing date was confirmed through spike development checked with a Dino-Lite digital microscope (AM411 Version 1.4.1; Vidy Precision Equipment Co. Ltd, Wuxi, China).

\section{Mechano-stimulation and cold treatments}

To investigate the effects of mechano-stimulation applied at different stages on seedling performance under cold stress, four treatments were imposed: $\mathrm{P}_{1} \mathrm{~L}$, the early priming of mechano-stimulation for plants was applied at the Zadoks growth stage 26 (25 March 2012) and then subjected to a 4-day cold event at the Zadoks growth 31 (jointing stage, 8-12 April 2012); $\mathrm{P}_{2} \mathrm{~L}$, the later mechano-stimulation for plants was carried out 6 days before the cold event (2 April 2012); CL, the cold stress at jointing without early mechano-stimulation; $\mathrm{CC}$, the normal temperature control. Mechano-stimulation was carried out using a cylinder roller with weight of $150 \mathrm{~kg}$ and diameter of $40 \mathrm{~cm}$. The roller was rolled over 
the wheat plants with a pressure of $7000 \mathrm{~N} \cdot \mathrm{m}^{-2}$ at 9:009:30 am, which resulted in less than $20 \%$ of the leaf area being damaged at jointing A 4-day cold stress was applied using four temperature control systems operated in the open top chamber condition. Air was cooled by a compressor, and then the cooled air was driven by an air blower to the field through ducting [16]. During cold treatment, plots were surrounded by $180-\mathrm{cm}$-high plastic film. All tubes were removed just after cooling treatment to avoid shading. Six temperature and humidity sensors were used to record the real-time data in each plot. The mean temperature in the cold treatment was $5.60{ }^{\circ} \mathrm{C}$ lower than the normal temperature control. The mean temperature at night was $-1.14{ }^{\circ} \mathrm{C}$, and the lowest temperature recorded during the cold treatment was $-4.97^{\circ} \mathrm{C}$ (detailed temperature data are shown in Additional file 1: Figure S1). The experiment had a split-plot design with temperature treatment as the main plot and wheat cultivar as the subplot, with three replicates for each treatment. The size of each plot was $3 \mathrm{~m} \times 4 \mathrm{~m}$.

\section{Chl a fluorescence transient}

The fast chlorophyll a fluorescence induction curve was measured using a Plant Efficiency Analyzer (PocketPEA; Hansatech, Norfolk, UK) [17]. Before measuring, plants were dark adapted for $0.5 \mathrm{~h}$. The collected data were processed by the program PEA Plus 1.04, and Biolyzer 3.0 software (Bioenergetics Lab., Geneva, Switzerland, http://www.fluoromatics.com/biolyzer_software-1.php) was used to calculate the fast chlorophyll a fluorescence induction (OJIP) test parameters.

\section{Chloroplast extraction and enzyme activity analysis}

Chloroplasts were isolated and purified from the latest fully expanded leaves following our previous method with a few modifications [16]. Leaf samples (6 g) were ground in $30 \mathrm{ml}$ of extraction buffer $(0.45 \mathrm{M}$ sucrose, $15 \mathrm{mM} \mathrm{3-}$ ( $N$-morpholino) propanesulfonic acid (MOPS), $1.5 \mathrm{mM}$ ethylene glycol tetraacetic acid (EGTA), $0.6 \%$ polyvinylpyrro-lidone (PVP), $0.2 \%$ bovine serum albumin (BSA), $0.2 \mathrm{mM}$ phenylmethylsulphonyl fluoride (PMSF) and $10 \mathrm{mM}$ dithiothreitol (DTT)). The homogenate was filtered through eight layers of gauze, and the filtrate was then centrifuged at $2000 \times g$ for $5 \mathrm{~min}$. The sediment was resuspended with sorbitol resuspension medium (SRM, $0.33 \mathrm{M}$ sorbitol in $50 \mathrm{mM}$ 4-(2hydroxyethyl)-1-piperazineethanesulfonic acid (HEPES)), and then layered on the top of a 7-ml layered system (35\%, $80 \%$ Percoll) for step gradients. The chloroplasts were collected and washed with $2 \mathrm{ml} \mathrm{SRM} \mathrm{followed} \mathrm{by}$ centrifugation at $1100 \times g$ for $10 \mathrm{~min}$. Finally, the intact chloroplasts were maintained in $2 \mathrm{ml} \mathrm{SRM}$ at $-4{ }^{\circ} \mathrm{C}$.
Following the methods of Zheng et al. [18], $\mathrm{H}_{2} \mathrm{O}_{2}$ concentration was measured by monitoring the absorbance of titanium peroxide complex at $410 \mathrm{~nm}$, and the release rate of $\mathrm{O}_{2}^{-}$was determined at an absorbance at $530 \mathrm{~nm}$. APX (EC 1.11.1.11) activity was determined by monitoring the decrease in absorbance at $290 \mathrm{~nm}$, the activity of SOD (EC 1.15.1.1) was measured by monitoring the inhibition of photochemical reduction of nitroblue tetrazolium (NBT), and GPX (EC 1.11.1.7) activity was calculated by monitoring the increase in absorbance at $470 \mathrm{~nm}$ due to the oxidation of guaiacol. GR (EC 1.6.4.2) activity was determined by the oxidation of NADPH at $340 \mathrm{~nm}$, and CAT (EC 1.11.1.6) activity was measured following the method of Tan et al. [19]. DHAR (EC 1.8.5.1) was assayed by monitoring changes in absorbance at $265 \mathrm{~nm}$ after the addition of ascorbate oxidase as described by Miyake and Asada [20]. The activities of $\mathrm{Ca}^{2+}$-ATPase and $\mathrm{Mg}^{2+}$-ATPase in the chloroplasts suspension were measured following the method of Zheng et al. [18].

\section{Rubisco activity}

Leaf samples $(0.2 \mathrm{~g})$ were ground in $40 \mathrm{ml}$ of extraction buffer (50 mM Tris-HCl, $1 \mathrm{mM}$ EDTA, $1 \mathrm{mM} \mathrm{MgCl}_{2}$, $10 \%$ PVP and $10 \mathrm{mM} \beta$-mercaptoethanol), and then centrifuged at $15000 \times g$ for $15 \mathrm{~min}$. The supernatant was gently collected to measure Rubisco activity. The activity of Rubisco (EC 4.1.1.39) before (initial activity) and after (total activity) active site carbamylation was assayed using a spectrophotometric procedure coupled to NADH oxidation [21]. Rubisco activation was estimated as the percentage ratio of initial to total activities for each sample.

\section{Protein extraction and 2-DE procedure}

The extraction of protein in the latest fully expanded leave for $2 \mathrm{DE}$ was performed following the trichloroacetic acid (TCA) acetone precipitation method described by Ding et al. [22].

Immobiline DryStrip gels (117 cm length: Bio-Rad) were used for first dimension isoelectrofocusing (IEF) at $\mathrm{pH} 4$ to 7 . Rehydration and focus were performed using PROTEAN IEF apparatus (Bio-Rad) at $50 \mu \mathrm{A}$ per strip at $20{ }^{\circ} \mathrm{C}$, using the following programme: $12 \mathrm{~h}$ of rehydration at $50 \mathrm{~V}$ in rehydration buffer $(7 \mathrm{M}$ urea, $2 \mathrm{M}$ thiourea, $4 \%(\mathrm{w} / \mathrm{v})$ CHAPS, $0.5 \%$ (v/v) IPG buffer, $10 \mathrm{mM}$ DTT, and $0.1 \%$ bromophenol blue), $1 \mathrm{~h}$ at $500 \mathrm{~V}, 1 \mathrm{~h}$ at $1000 \mathrm{~V}, 2 \mathrm{~h}$ at $8000 \mathrm{~V}$, and $85000 \mathrm{~V}$. hours at $8000 \mathrm{~V}$. After dimension isoelectrofocusing, strips were equilibrated for $15 \mathrm{~min}$ in SDS equilibration buffer solution (6 M urea, $37.5 \mathrm{mM}$ Tris- $\mathrm{HCl}(\mathrm{pH} 6.8), 20 \%$ (v/v) glycerol, $2 \%(\mathrm{w} / \mathrm{v})$ SDS, and $1 \%(\mathrm{w} / \mathrm{v})$ DTT), followed by equilibration with a buffer containing $135 \mathrm{mM}$ iodoacetamide for $15 \mathrm{~min}$. After equilibration, proteins were 
distributed in the second dimension (SDS-PAGE) using $10 \%$ polyacrylamide gels $(250 \times 200 \times 1 \mathrm{~mm})$, and the gels were stained with silver nitrate solution.

\section{Image analysis, protein identification, and functional annotation}

The gels were scanned using a VersaDoc4000 image system (Bio-Rad) and the images were analysed with PDQUEST 8.0 software (Bio-Rad, USA). There were three biological replicates per treatment with at least three gels for each biological replicate. Only spots with a variation rate of \pm 0.5 in the three replicates were considered for further analysis. Stained protein spots were excised manually from the gels, in-gel digested with trypsin, and analysed using a MALDI-TOF/TOF mass spectrometer (ABI 4800). The MASCOT database search engine (http://matrixscience.com) was used to search for peptide mass lists from the obtained spectra against the NCBI database. The mass error tolerance was set to $80 \mathrm{ppm}$, and the score threshold was above or equal to 110 .

RNA extraction and qRT-PCR for gene expression analysis RNA was extracted from wheat leaves using Trizol according to the manufacturer's instructions. The genespecific primers were constructed using the Primer 3 programme, on the basis of wheat gene sequences in the GenBank (http://www.ncbi.nlm.nih.gov/) [23]. The following primers were used for amplification: $\mathrm{Cu} / \mathrm{Zn}$ $S O D, 5^{\prime}$-CGCTCAGAGCCTCCTCTTT-3' and 5' -CTC CTGGGGTGGAGACAAT-3'; Fe SOD, 5'-GAAGCTT GAGGTGGCACA-3' and 5'-TAAGCATGCTCCCAC AAGTC-3'; CAT, 5'-CCATGAGATCAAGGCCATCT$3^{\prime}$ and 5'-ATCTTACATGCTCGGCTTGG-3'; $t A P X$, 5'-G CAGCTGCTGAAGGAGAAGT-3' and 5' -CACT GGGGCCACTCACTAAT-3'; $\beta$-actin, $5 '$ - GCTCGAC TCTGGTGATGGTG-3' and 5'- AGCAAGGTCCAAAC GAAGGA-3'. The qPCR analysis was performed using the TaKaRa ${ }^{\oplus}$ SYBR Premix Ex Taq ${ }^{\text {TM }}$ II on an ABI PRISM 7300 Sequence Detection System (ABI, Foster, CA, USA). The PCR conditions consisted of denaturation at $95{ }^{\circ} \mathrm{C}$ for $3 \mathrm{~min}$, followed by 40 cycles of denaturation at $95{ }^{\circ} \mathrm{C}$ for $15 \mathrm{~s}$, annealing at $54{ }^{\circ} \mathrm{C}$ for $20 \mathrm{~s}$, and extension at $72{ }^{\circ} \mathrm{C}$ for $18 \mathrm{~s}$. To minimize sample variations, $\beta$-actin was used as the reference gene. Each extraction and qRT-PCR was replicated three times. The quantification of mRNA levels was based on the relative quantification method $\left(2^{-\Delta \Delta C t}\right)[24]$.

\section{Statistical analysis}

All data were subjected to the two-way ANOVA using the SigmaSATA (Systat Software Inc., CA, USA). The Duncan's multiple range test was used to check the significance of difference between treatments. In 2-DE analysis, the difference of expression level at the given protein spots between treatments and the control (CC) for each cultivar was calculated and converted to a color scale by PageMan software (http://mapman.mpimpgolm.mpg.de/pageman/).

\section{Results}

\section{Chl a fluorescence transient}

The increase in leaf fluorescence transients observed in CC treatment showed a typical OJIP shape in YN19 and LM6 (Fig. 1a, c). However, $\mathrm{P}_{1} \mathrm{~L}$ (early mechano-stimulation + cold stress), $\mathrm{P}_{2} \mathrm{~L}$, (later mechano-stimulation + cold stress) and $\mathrm{CL}$ (non-mechano-stimulation + cold stress) showed repressed fluorescence transients in these two cultivars, particularly at step I $(30 \mathrm{~ms})$ and $\mathrm{P}$. The main changes of fluorescence data were normalized between step I (30 ms) and $\mathrm{P}$ (300 $\mathrm{ms}$ ) and presented as relative variable fluorescence $\mathrm{W}_{\mathrm{IP}}$ (Fig. 1b, d). Obvious changes in $\mathrm{W}_{\mathrm{IP}}$ during the fast rise period were observed under $\mathrm{P}_{2} \mathrm{~L}$ and $\mathrm{CL}$ in $\mathrm{YN} 19$, while under $\mathrm{P}_{1} \mathrm{~L}, \mathrm{P}_{2} \mathrm{~L}$, and $\mathrm{CL}$ in $\mathrm{LM} 6$, compared with $\mathrm{CC}$. $\mathrm{W}_{\mathrm{OP}}\left(\right.$ Fig. 1e, g) and $\mathrm{W}_{\mathrm{OI}}$ (Fig. 1f, h) showed relatively variable fluorescence from $\mathrm{O}$ to step $\mathrm{P}(300 \mathrm{~ms})$ and from $\mathrm{O}$ to I (30 ms). A significant decrease in $\mathrm{W}_{\mathrm{OP}}$ at step I was found in $\mathrm{P}_{1} \mathrm{~L}, \mathrm{P}_{2} \mathrm{~L}$, and $\mathrm{CL}$ in $\mathrm{YN} 19$, while $\mathrm{W}_{\mathrm{OP}}$ was increased remarkably by $\mathrm{P}_{2} \mathrm{~L}$ at step I in LM6. Significant changes in $\mathrm{W}_{\mathrm{OI}}$ were found among $\mathrm{P}_{1} \mathrm{~L}, \mathrm{P}_{2} \mathrm{~L}$, and $\mathrm{CL}$ treatments in YN19, which were related to the reductions between PSI and reduced $\mathrm{NADP}^{+}$. However, with the exception of the $\mathrm{P}_{2} \mathrm{~L}$ treatment, $\mathrm{W}_{\mathrm{OI}}$ was only slightly affected in LM6.

\section{Rubisco activities and activation}

Initial and total Rubisco activities and Rubisco activation in the latest fully expanded leaves were significantly decreased with CL, compared with CC in YN19 and LM6 (Fig. 2, $P<0.001$ ). Both traits were slightly and marginally significantly increased by $\mathrm{P}_{1} \mathrm{~L} \quad(P=0.077)$, whereas they were depressed by $\mathrm{P}_{2} \mathrm{~L}$ compared with CL $(P<0.001)$. Rubisco activation in $\mathrm{P}_{1} \mathrm{~L}$ was relatively higher than in $C L$, but was still lower than in $\mathrm{CC}$ for both cultivars $(P<0.001)$. In addition, no difference in Rubisco activation was found between $\mathrm{P}_{2} \mathrm{~L}$ and CL.

\section{ROS production, activities of antioxidant enzymes, and expressions of their encoding genes in chloroplasts} In $\mathrm{YN} 19, \mathrm{CL}$ increased the concentration of $\mathrm{H}_{2} \mathrm{O}_{2}$ in chloroplasts in the latest fully expanded leaves by $63 \%$ as compared with $\mathrm{CC}$, whereas $\mathrm{P}_{2} \mathrm{~L}$ showed a $34 \%$ increment compared with CL (Fig. 3a). However, no difference was observed between $\mathrm{CC}$ and $\mathrm{P}_{1} \mathrm{~L}$. A similar pattern was observed in LM6. The highest rate of $\mathrm{O}_{2}^{-}$ release was found in $\mathrm{P}_{2} \mathrm{~L}$, followed by $\mathrm{CL}$ and $\mathrm{P}_{1} \mathrm{~L}$, whereas that in $\mathrm{CC}$ was lowest in both cultivars (Fig. 3b, $P<0.001)$. SOD activity in chloroplasts was increased 


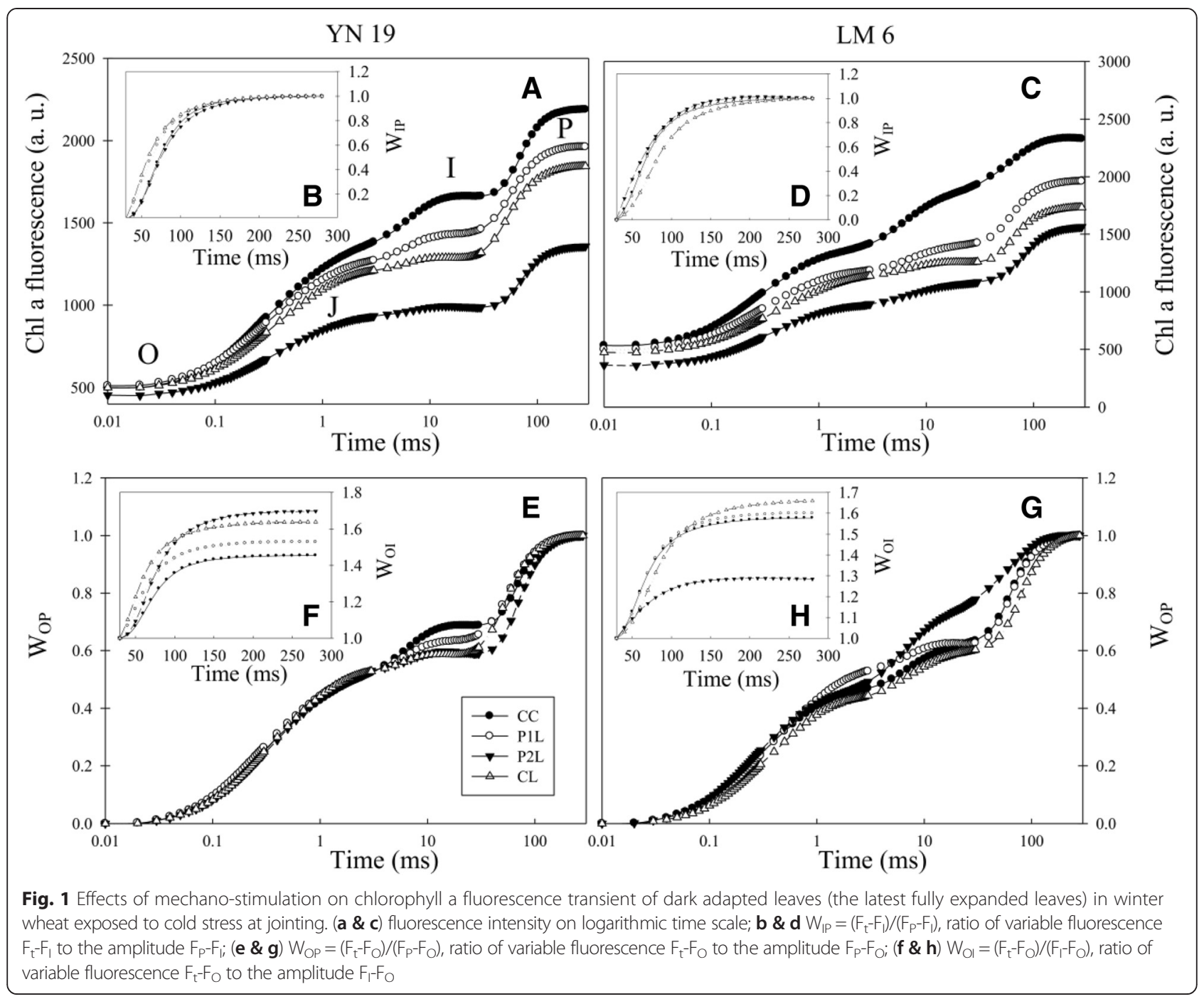

by $16 \%$ and $25 \%$ with $\mathrm{P}_{1} \mathrm{~L}$ in $\mathrm{YN} 19$ and LM6, respectively. Compared with $\mathrm{CC}, \mathrm{P}_{1} \mathrm{~L}$ increased while $\mathrm{P}_{2} \mathrm{~L}$ and CL significantly decreased chloroplastic SOD activity in the two cultivars (Fig. 3c). In addition, in both cultivars, expression of $\mathrm{Cu} / \mathrm{Zn} S O D$ was up-regulated by $\mathrm{P}_{1} \mathrm{~L}$ compared with CL (Fig. 4a), whereas an up-regulation of $\mathrm{Fe} S O D$ due to $\mathrm{P}_{1} \mathrm{~L}$ was only observed in $\mathrm{YN} 19$ (Fig. 4b). For both cultivars, CAT activity was lower in $\mathrm{CL}$ than in $\mathrm{CC}$, whereas it was higher in $\mathrm{P}_{1} \mathrm{~L}$ than in CL (Fig. 3d). In LM6, $\mathrm{P}_{2} \mathrm{~L}$ decreased CAT activity by $20 \%$ compared with $\mathrm{CL}$, whereas no significant difference was found in YN19 $(P=0.112)$. An increase in the expression of $C A T$ was found in $\mathrm{P}_{1} \mathrm{~L}$ and $\mathrm{P}_{2} \mathrm{~L}$ compared with $\mathrm{CL}$ in YN19; however, the difference was not statistically significant (Fig. 4c). In both cultivars, the combination of mechano-stimulation and low temperature $\left(\mathrm{P}_{1} \mathrm{~L}\right.$ and $\left.\mathrm{P}_{2} \mathrm{~L}\right)$ and CL enhanced APX activity compared with CC. In particular APX activity in $\mathrm{P}_{2} \mathrm{~L}$ was significantly higher than in CL (Fig. 3e). Further, the same trend was found in thylakoid-bound APX (tAPX) expressions in YN19, whereas in LM6, a significant up-regulation of $t A P X$ was only observed in $\mathrm{P}_{1} \mathrm{~L}$ (Fig. $4 \mathrm{~d}$ ). In both cultivars, GPX activity was enhanced with $\mathrm{P}_{1} \mathrm{~L}$, but depressed with $\mathrm{P}_{2} \mathrm{~L}$ and $\mathrm{CL}$ (no significant difference between $\mathrm{P}_{2} \mathrm{~L}$ and $\mathrm{CL}$ ) (Fig. 3f). In both cultivars, $\mathrm{P}_{1} \mathrm{~L}$ and $\mathrm{CL}$ resulted in a significant increase in GPX activity, compared with CC $(P<0.001)$, whereas $\mathrm{P}_{2} \mathrm{~L}$ slightly increased GPX activity (Fig. $3 g, P=0.105$ ). Low temperature significantly enhanced DHAR activity in both cultivars $(P<0.001)$; however, $\mathrm{P}_{1} \mathrm{~L}$ and $\mathrm{P}_{2} \mathrm{~L}$ had opposite effects on DHAR activity in the two cultivars-namely, $\mathrm{P}_{2} \mathrm{~L}$ decreased DHAR activity compared to CL in YN19, but increased activity in LM6; $\mathrm{P}_{1} \mathrm{~L}$ increased DHAR activity in LM6, whereas no difference between $\mathrm{P}_{1} \mathrm{~L}$ and $\mathrm{CL}$ was found in $\mathrm{YN} 19$ (Fig. 3h). Thus, $\mathrm{P}_{1} \mathrm{~L}$ and $\mathrm{P}_{2} \mathrm{~L}$ showed opposite patterns in the concentration of $\mathrm{H}_{2} \mathrm{O}_{2}$ in chloroplasts, $\mathrm{O}_{2}^{-}$release rate and most of the antioxidant enzyme activities, but the APX activity showed a similar trend in $\mathrm{P}_{1} \mathrm{~L}$ and $\mathrm{P}_{2} \mathrm{~L}$. 


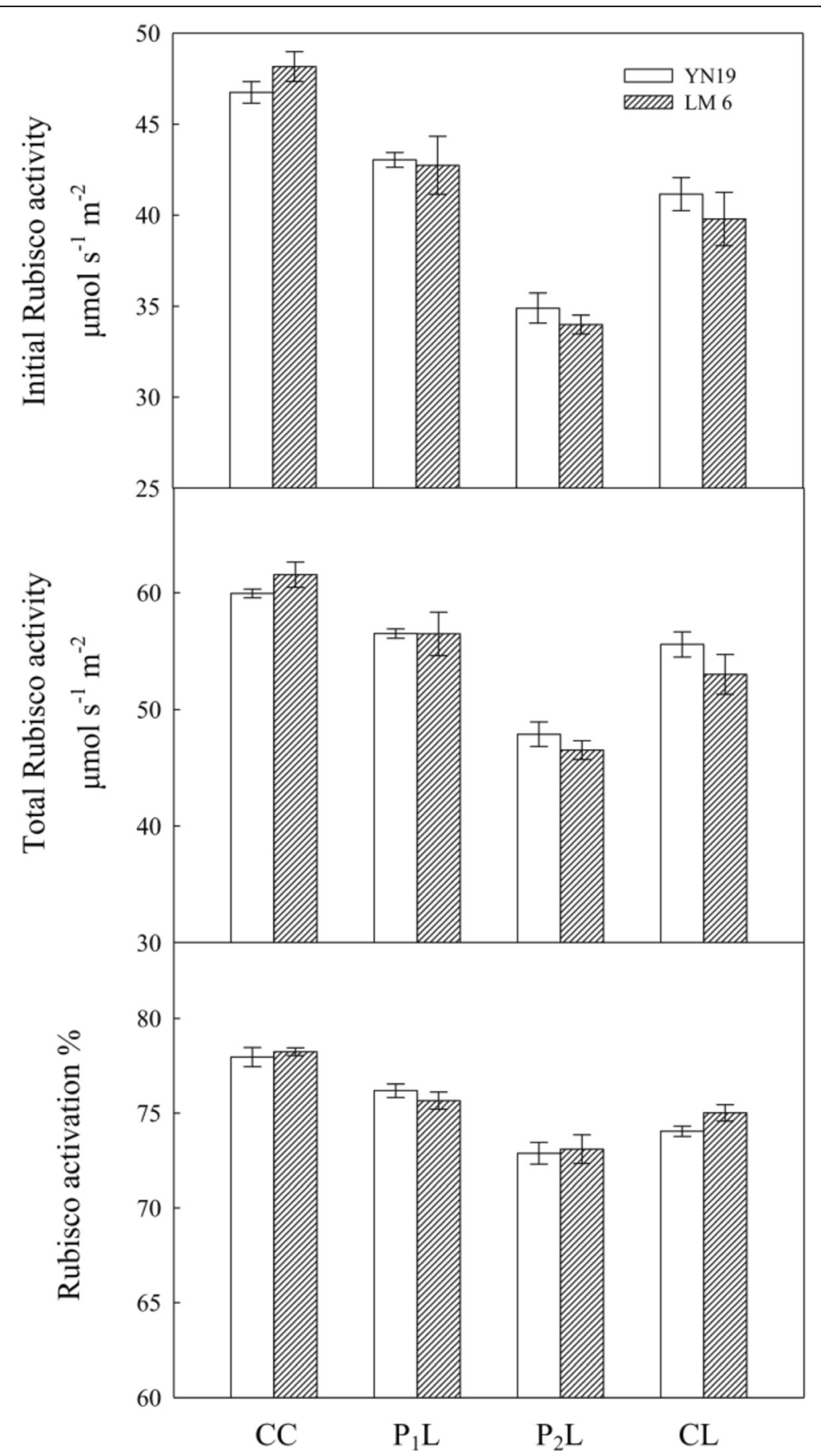

Fig. 2 Effects of mechano-stimulation on initial and total Rubisco activities and activation in the latest fully expanded leaves in winter wheat exposed to cold stress at jointing

\section{ATPase activities in chloroplasts}

In YN19, the Activities of both $\mathrm{Mg}^{2+}$-ATPase and $\mathrm{Ca}^{2+}$-ATPase were significantly decreased by $\mathrm{CL}$ as compared with CC (Fig. 5, $P<0.001$ ). However, both ATPase activities were increased by $\mathrm{P}_{1} \mathrm{~L}$, whereas they decreased by $\mathrm{P}_{2} \mathrm{~L}$. The activities of $\mathrm{Mg}^{2+}$-ATPase and
$\mathrm{Ca}^{2+}$-ATPase in LM6 in response to different treatments were similar to those in YN19.

\section{Proteomics}

The reference 2-DE gel of proteins in wheat leaves affected by combination of mechano-stimulation and cold 


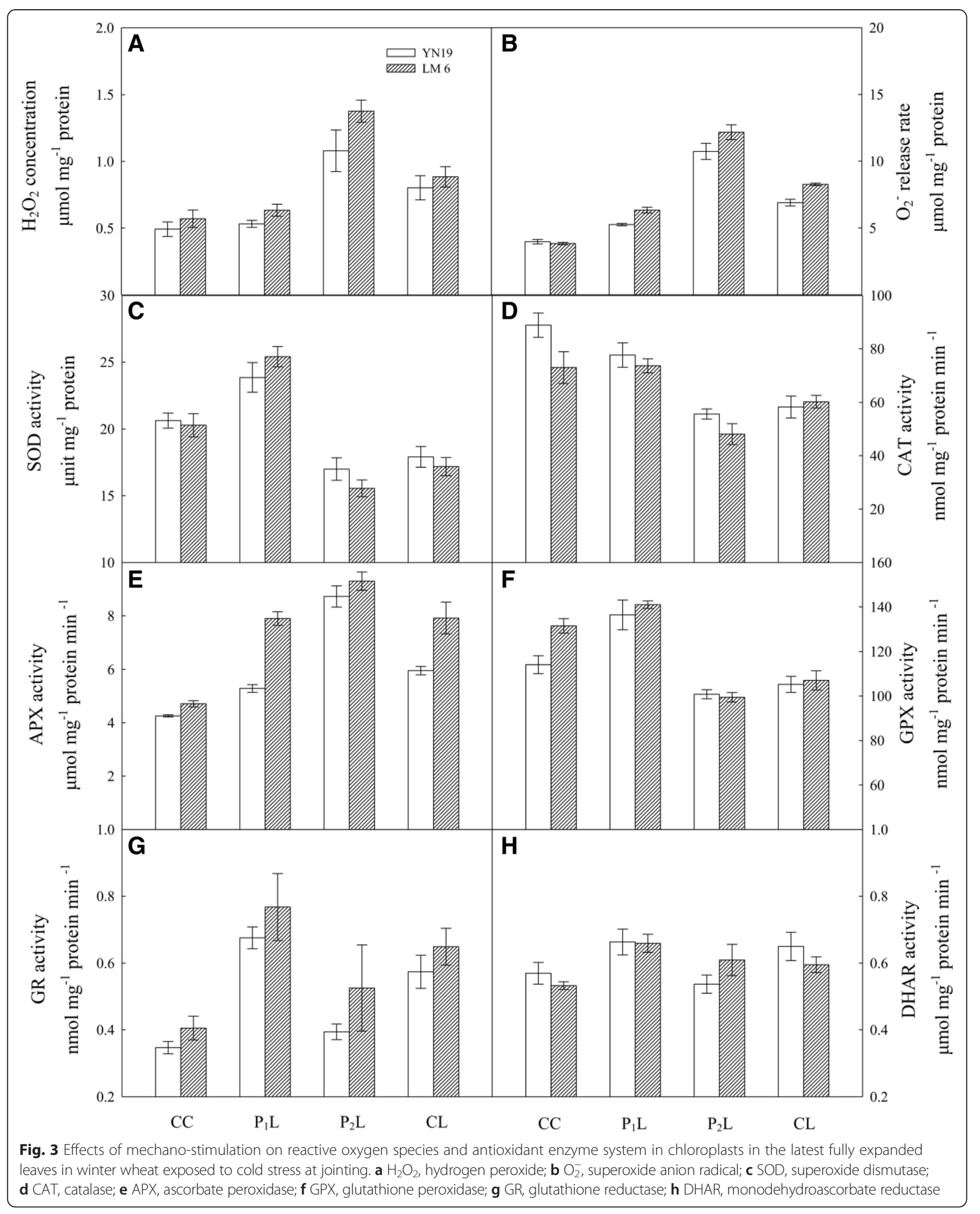




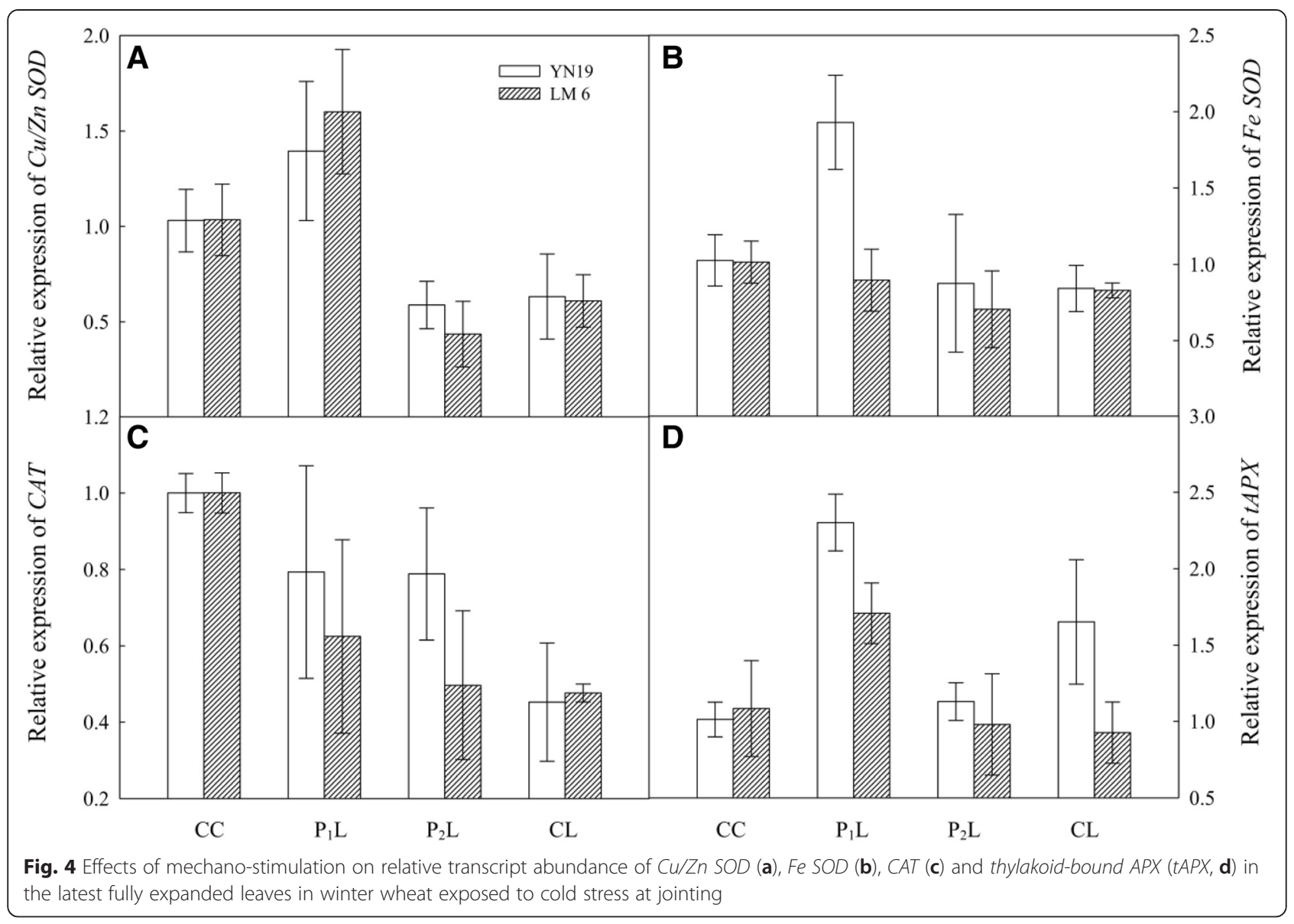

stress is shown in Fig. 6. More than 600 protein spots were detected in each gel. To demonstrate the proteomic response of the photosynthetic apparatus to mechano-stimulation and cold stress, variation in the expression of 12 protein spots related to photosynthesis, energy production, stress defense in chloroplasts is specifically shown in Fig. 7. The differentially expressed protein spots were identified by mass spectrometry (MS, Table 1). In the cluster related to photosynthesis, five protein spots, including enzymes involved in the Calvin cycle and Rubisco protein subunit-ferredoxin-NADP(H) oxidoreductase (spot 10), ribulose-1, 5-bisphosphate carboxylase activase (spot 11) and the Rubisco large subunitbinding protein subunit alpha (6)-were up-regulated by $\mathrm{P}_{1} \mathrm{~L}$ in both cultivars; the exception being spot 10 , which was missing in $\mathrm{P}_{1} \mathrm{~L}$ in $\mathrm{YN} 19$. CL induced up-regulation in chloroplastic glutathione reductase (spot 5 ) and ascorbate peroxidase (spot 7) in both cultivars, whereas the expression of catalase-1 (spot 8) was down-regulated by CL. These proteins were, however, all up-regulated by $\mathrm{P}_{1} \mathrm{~L}$ in both cultivars, except for catalase-1 in YN19. In addition, in both cultivars, the expression of ATP synthase $\beta$ subunit (spot 9) was depressed by CL compared with CC, but was increased by $\mathrm{P}_{1} \mathrm{~L}$ compared with $\mathrm{CL}$. Interestingly, the chloroplastic fructose-bisphosphate aldolase (spot 2) was up-regulated by $\mathrm{CL}$ in the two cultivars, whereas under $\mathrm{P}_{1} \mathrm{~L}$, it was decreased in YN19 but increased in LM6. Proteomic analyses revealed that the oxidative stress defense, ATP synthesis, and photosynthesis-related proteins were similarly modulated by the mechanostimulation and the cold stress.

\section{Discussion}

It is well known that ROS production is a universal response to mechanical wounding in various plants [11]. The defense system can also be activated to alleviate ROS-induced oxidative stress and repair the damaged tissues [25]. Furthermore, many of the genes encoding enzymes involved in ROS metabolism are regulated by mechanical wounding [26]. Here, the leaf chloroplastic $\mathrm{H}_{2} \mathrm{O}_{2}$ concentration in $\mathrm{P}_{1} \mathrm{~L}$ plants was very close to that in CC plants. In contrast, $\mathrm{P}_{2} \mathrm{~L}$ plants have a significantly higher $\mathrm{H}_{2} \mathrm{O}_{2}$ concentration than CC plants (Fig. 3). This difference is related to the efficient ROS scavenging capacity of the antioxidant enzyme systems, particularly the water-water cycle in chloroplasts, which mainly includes SOD and APX [27]. The scavenging capacity of SOD and CAT activated by the mechano-stimulation in $\mathrm{P}_{1} \mathrm{~L}$ 


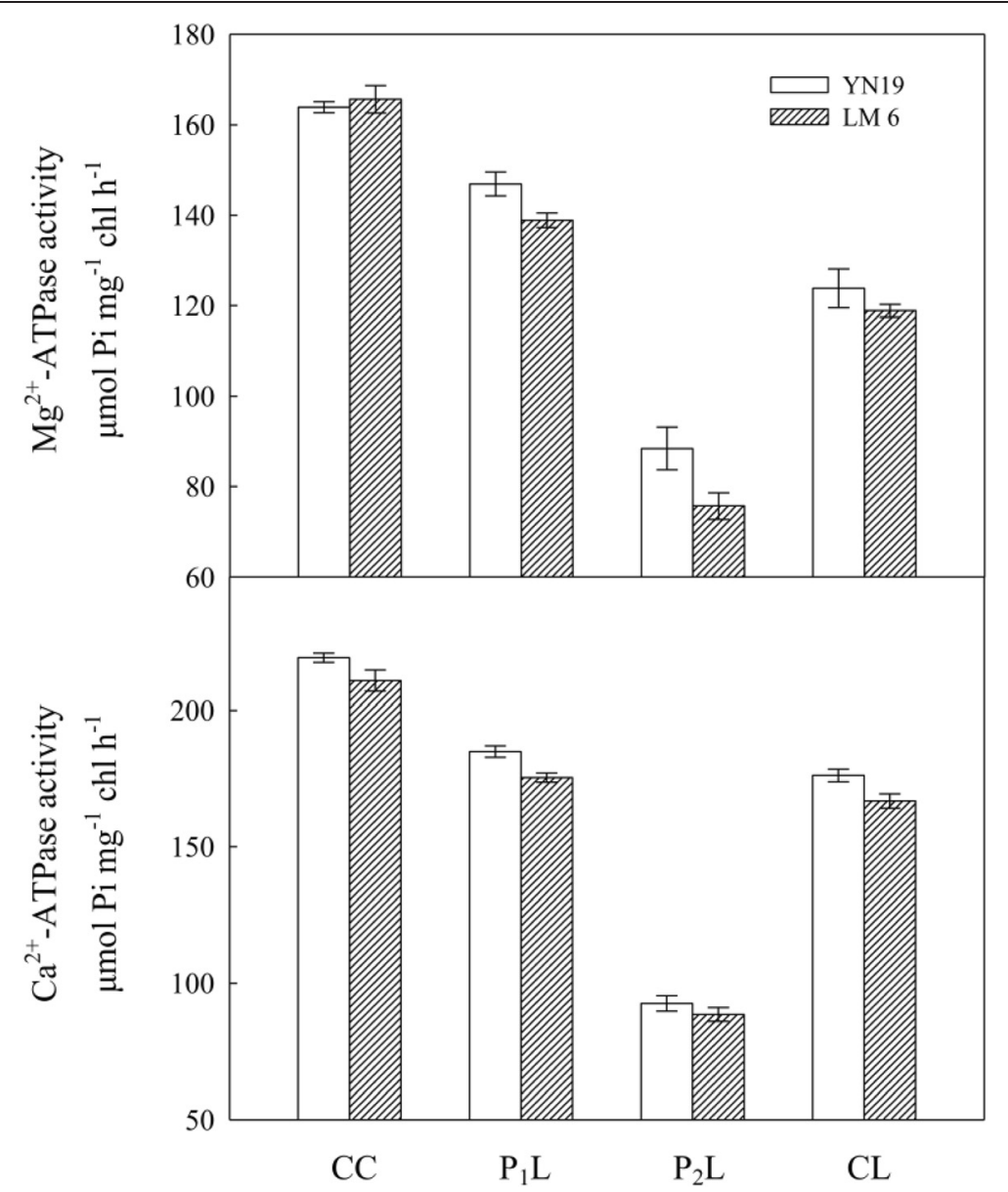

Fig. 5 Effects of mechano-stimulation on activities of $\mathrm{Mg}^{2+}$-ATPase and $\mathrm{Ca}^{2+}$-ATPase in chloroplasts in the latest fully expanded leaves in winter wheat exposed to cold stress at jointing

had a significant inhibitory effect on the oxidative burst under low temperature stress. Further analysis revealed that the enhanced activities of SOD and CAT could be largely explained by the up-regulated expression of $\mathrm{Cu} /$ $\mathrm{Zn} \mathrm{SOD,Fe} S O D$, and $C A T$ in $\mathrm{P}_{1} \mathrm{~L}$ (Fig. 7). Woundinduced activation of $\mathrm{H}_{2} \mathrm{O}_{2}$-detoxifying enzymes has previously been demonstrated using proteomic tools [26]. Our proteome analysis showed that the expression levels of ascorbate peroxidase and catalase- 1 were paralleled by the activities of APX and CAT, respectively, under different treatments (Fig. 7). However, in YN19, the activity of APX in $\mathrm{P}_{1} \mathrm{~L}$ was decreased compared to CL, whereas no significant difference was found in LM6. The qPCR analysis also showed that the $t A P X$ expression was only slightly affected by P1L in YN19, but it was increased by $\mathrm{P}_{1} \mathrm{~L}$ in LM6. APX activity under the combination of mechano-stimulation and cold stress was only partly consistent with that previously reported. It has been reported that expression of ascorbate peroxidase 2 (APX2) is involved in modulation of cellular $\mathrm{H}_{2} \mathrm{O}_{2}$ levels in response to wounding [15, 26, 27]. The increase in APX activity in $\mathrm{P}_{2} \mathrm{~L}$ and no increase in $\mathrm{P}_{1} \mathrm{~L}$ suggested that APX may not play vitally important roles in the mechano-induced cold tolerance in wheat.

Increasing evidence supports the multi-signaling functions of $\mathrm{H}_{2} \mathrm{O}_{2}$ in response to abiotic stresses in higher plants [11]. Here, under low temperature, for both texted cultivars the $\mathrm{H}_{2} \mathrm{O}_{2}$ concentration in $\mathrm{P}_{1} \mathrm{~L}$ was very close to the normal level in CC. However, the release rate of $\mathrm{O}_{2}^{-}$in $\mathrm{P}_{1} \mathrm{~L}$ was significantly higher than in $\mathrm{CC}$. It was suggested that activated antioxidative enzymes, such as SOD and CAT induced by mechano-stimulation, modify the $\mathrm{H}_{2} \mathrm{O}_{2}$ concentration to an appropriate level as a signal molecule, which prevents $\mathrm{H}_{2} \mathrm{O}_{2}$-induced damage to plant tissues [11]. In addition, modified GPX and GR activities have also been shown to be related to the down-regulation of $\mathrm{H}_{2} \mathrm{O}_{2}$ levels in chloroplasts [28]. Here, the increased activities of GPX and GR did favour the relatively low level of $\mathrm{H}_{2} \mathrm{O}_{2}$ in $\mathrm{P}_{1} \mathrm{~L}$ (Fig. 3). Although the concentrations of AsA and GSH are only in the millimolar range in plant tissues, the AsA-GSH cycle plays a very important role in neutralizing $\mathrm{H}_{2} \mathrm{O}_{2}$ released by 


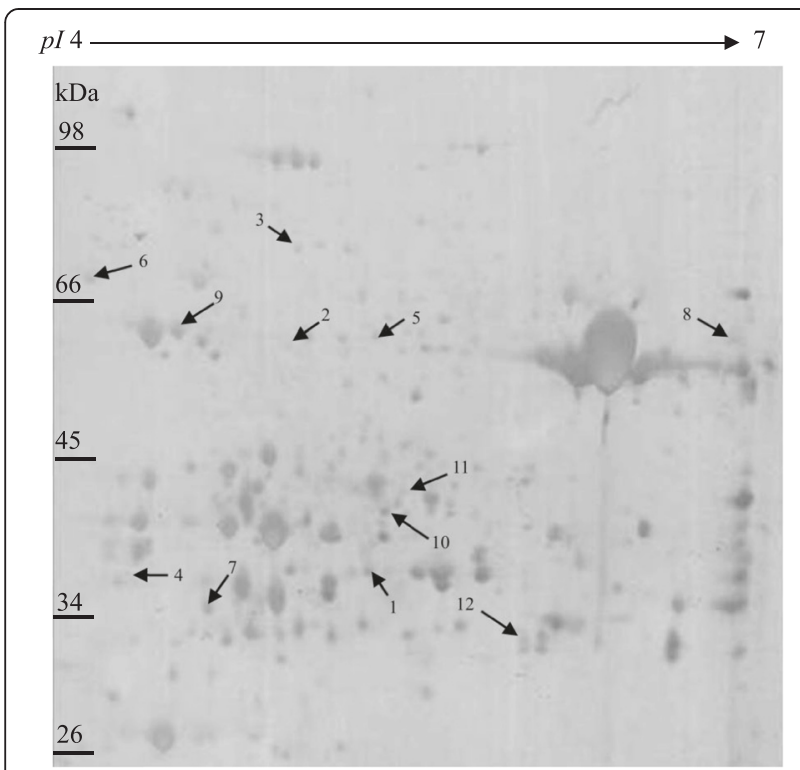

Fig. 6 Reference 2-DE gel of proteins in wheat leaves under combination of mechano-stimulation and jointing cold stress. Differentially expressed protein spots in stress treatments $\left(C L, P_{1} L\right.$ and $P_{2} L$ ) compared with $C C$ for each cultivar were indicated with arrows and listed in Table 1

disproportionation of $\mathrm{O}_{2}^{-}$[28]. As key members in the AsA-GSH cycle, the altered expression of glutathione reductase (GR)- and dehydroascorbate reductase (DHAR)related proteins were found via proteome analysis in the present study; chloroplastic GR was increased in $\mathrm{P}_{1} \mathrm{~L}$ in both cultivars, whereas DHAR was enhanced in $\mathrm{P}_{1} \mathrm{~L}$ only in LM6 compared to CL (Fig. 7). The changes in expression of these enzymes are in accordance with their activities in chloroplasts. Thus, we suggest that the AsA-GSH cycle is involved in mechano-stimulated cold tolerance in winter wheat.

Hardening with a previous abiotic stress endows plant with higher tolerance to recurring stresses [29]. For example, pre-anthesis heat hardening (or pre-treatment) can partially protect wheat plants from photosynthetic inhibition and oxidative damage under post-anthesis high-temperature stress, which is attributed to the modified expressions of photosynthesis-responsive and antioxidant enzyme-related genes [30]. Furthermore, many studies have shown that the mechanism underlying hardening includes the accumulation of soluble sugars, reduction of photosynthetic apparatus [30], scavenging of reactive oxygen species (ROS) [30], accumulation of osmoprotective proteins (dehydrins) [31], and other compatible solutes such as proline and betaína [31]. It is well known that cold acclimation reduces frost damage, and that this phenomenon involves a mechanism similar to that of drought acclimation [32]. Mechano-stimulation may induce many types of cold response proteins and genes [8]. In addition to the antioxidant system activated by mechano-stimulation, shown in the present study, many types of proteins related to photosynthesis, energy production, and $\mathrm{C}$ metabolism were modified by mechano-stimulation (Fig. 7). With respect to photosynthetic $C$ assimilation, ribulose-1, 5-biophosphate carboxylase activase and its isoform 1 had a higher level of expression in $\mathrm{P}_{1} \mathrm{~L}$, but a relatively low level in $\mathrm{CL}$, in the two tested cultivars. Ribulose-1, 5biophosphate carboxylase activase and Rubisco large subunit-binding protein have been shown to play a critical role in the activation of Rubisco [33]. Carbonic anhydrase enhances the $\mathrm{CO}_{2}$ concentration in chloroplasts, which improves the carboxylation rate of

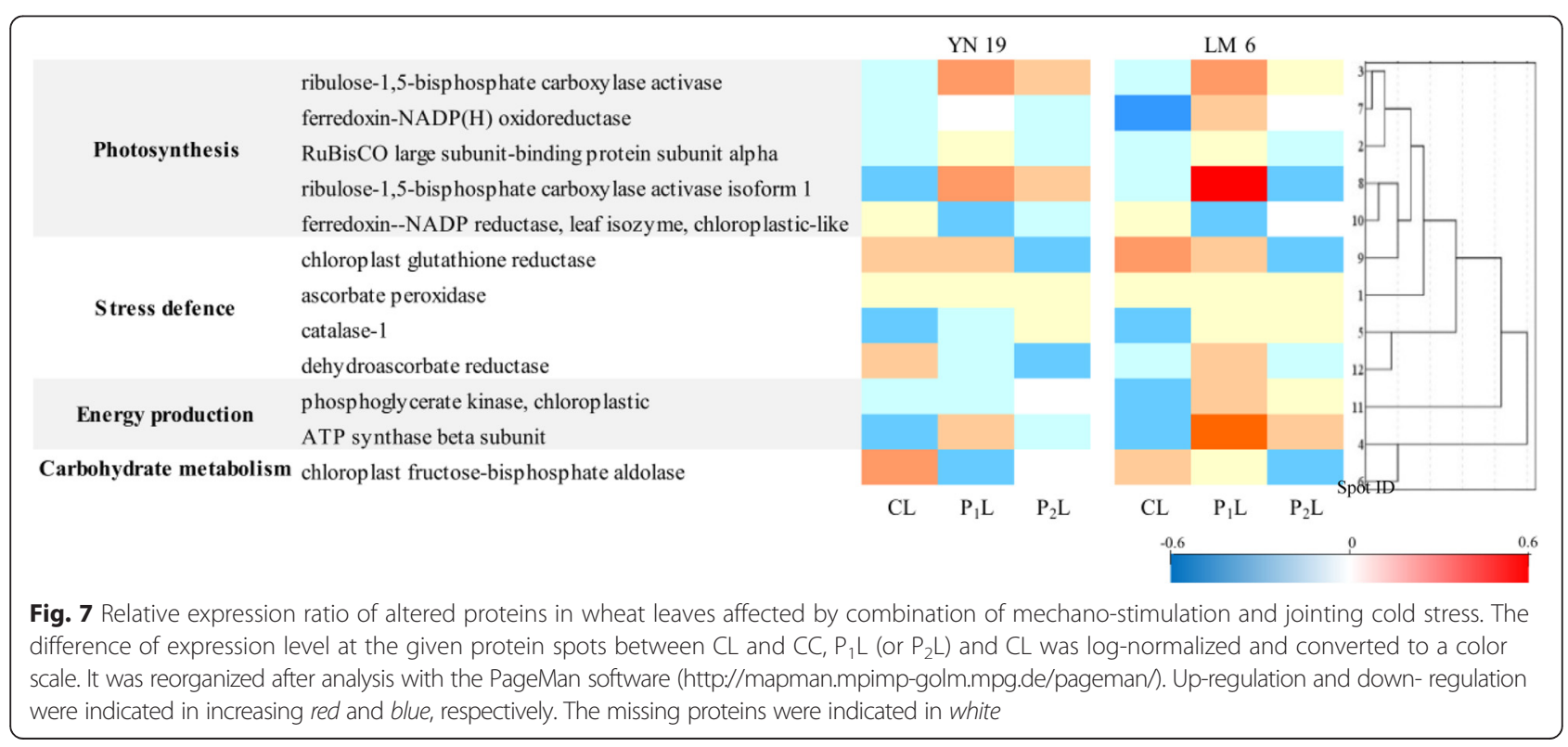


Table 1 Identification of differentially expressed proteins in wheat leaves affected by combination of mechano-stimulation and jointing cold stress through MALDI-TOF/TOF

\begin{tabular}{|c|c|c|c|c|c|c|}
\hline Spot ID & Protein name & Gl accession no. & Theor. Mr (kDa)/pl & Score & SC (\%) & Taxonomy \\
\hline 1 & $\begin{array}{l}\text { ferredoxin-NADP reductase, leaf isozyme, chloroplastic- } \\
\text { like }\end{array}$ & 357110920 & $40.81 / 6.72$ & 103 & 5 & Brachypodium distachyon \\
\hline 2 & chloroplast fructose-bisphosphate aldolase & 223018643 & $42.22 / 5.94$ & 800 & 30 & Triticum aestivum \\
\hline 3 & Phosphoglycerate kinase, chloroplastic & 129915 & $49.98 / 6.58$ & 323 & 10 & Triticum aestivum \\
\hline 4 & ribulose-1,5-bisphosphate carboxylase activase isoform 1 & 167096 & $47.37 / 8.62$ & 549 & 45 & Hordeum vulgare subsp \\
\hline 5 & chloroplast glutathione reductase & 148250114 & $50.87 / 6.17$ & 309 & 10 & Dasypyrum villosum \\
\hline 6 & $\begin{array}{l}\text { RuBisCO large subunit-binding protein subunit alpha, } \\
\text { chloroplastic precursor }\end{array}$ & 134102 & $57.66 / 4.83$ & 841 & 26 & Triticum aestivum \\
\hline 7 & ascorbate peroxidase & 15808779 & $27.96 / 5.10$ & 471 & 27 & $\begin{array}{l}\text { Hordeum vulgare subsp. } \\
\text { Vulgare }\end{array}$ \\
\hline 8 & catalase-1 & 2493543 & $57.00 / 6.52$ & 512 & 13 & Triticum aestivum \\
\hline 9 & ATP synthase beta subunit & 110915710 & $53.02 / 5.17$ & 326 & 17 & Vulpia microstachys \\
\hline 10 & ferredoxin-NADP(H) oxidoreductase & 20302473 & $40.49 / 6.92$ & 739 & 34 & Triticum aestivum \\
\hline 11 & ribulose-1,5-bisphosphate carboxylase activase & 37783283 & $22.49 / 4.98$ & 475 & 34 & Triticum aestivum \\
\hline 12 & dehydroascorbate reductase & 28192421 & $23.46 / 5.88$ & 118 & 22 & Triticum aestivum \\
\hline
\end{tabular}

Spot ID are named according to Fig. 6 . GI refers to accession number. NCBI refers to database accession number. Mr/pl refers to molecular weight and isoelectric point of identified protein. Score refers to Mascot protein score. SC refers to Sequence Coverage

Rubisco enzyme [21]. Our proteomic data also showed a higher abundance of Rubisco large subunit-binding protein subunit $\alpha$ in $\mathrm{P}_{1} \mathrm{~L}$ than that in $\mathrm{CL}$ in both cultivars. This implies increases in the Rubisco activation state and carboxylation rate induced in the early mechanostimulated plants under low temperature stress (Fig. 2). The unaltered expression of ferredoxin-NADP $(\mathrm{H})$ oxidoreductase and down-regulation of ferredoxin-NADP reductase, leaf isozyme, and chloroplastic-like protein in $\mathrm{P}_{1} \mathrm{~L}$ observed in the present study, resulted in an increased level of NADPH-dependent $\mathrm{H}_{2} \mathrm{O}_{2}$ as compared with CL. It has been suggested that increased NADPH-dependent $\mathrm{H}_{2} \mathrm{O}_{2}$ is required for the activation of systemic wound responses [11]. The mechano-stimulation induced $\mathrm{H}_{2} \mathrm{O}_{2}$ production is also involved in plant defence responses against invading pathogens [34]. It was reported that ROS can control $\mathrm{Ca}^{2+}$-permeable channel activity to regulate the intracellular $\mathrm{Ca}^{2+}$ level [35]. The changes of ROS and $\mathrm{Ca}^{2+}$ following mechano-stimuli were implicated in the induction of defense genes in response to fungal pathogens $[34,36]$.

Photosynthetic electron transport generates energy (ATP) and reducing power (NADPH) to support carbon reduction and photorespiratory carbon oxidation in the dark reaction in photosynthesis and plays a key role in the maintenance of optimum photosynthetic rate and ensuring effective energy flow for growth [37]. To further investigate the interactive effects of mechanostimulation and cold stress on the process of photosynthetic electron transport, transient fluorescence kinetics were analysed (Fig. 1). The I-P phase of the transient fluorescence kinetics revealed changes in the electron flux from $\mathrm{PQH}_{2}$ to the final electron acceptor and the size of the final electron acceptor pool of PS I [38]. The present study showed no significant effects of the combination of mechano-stimulation and cold stress on the electron flux from $\mathrm{PQH}_{2}$ to the final electron acceptor. However, the O-I part of the kinetics was affected by cold stress and mechanostimulation, which reveals changes in the process involving exciton capture to $\mathrm{PQ}$ reduction [38]. In addition, the rise in fluorescence transient from $\mathrm{O}$ to $\mathrm{P}$ was faster in $\mathrm{P}_{2} \mathrm{~L}$ in LM6, which indicates that the re-oxidation of $\mathrm{Q}_{\mathrm{A}}^{-}$was inhibited by the combination of cold and later mechano-stimulation [39]. However, it was not markedly affected by cold stress alone. The ATPases in chloroplasts, $\mathrm{Mg}^{2+}$-ATPase and $\mathrm{Ca}^{2+}$-ATPase, play a key role in ATP formation [18]. In this study, the activities of these two functional enzymes in chloroplasts were enhanced by mechano-stimulation in response to cold stress, which might favor the ATP formation. Consistently, the proteome data showed that, in both cultivars tested, there was a higher abundance of ATP synthase $\beta$ subunit in $\mathrm{P}_{1} \mathrm{~L}$.

\section{Conclusions}

Early mechano-stimulation at the stage of at Zadoks growth stage 26 activated the antioxidant system and hence maintained the balance of reactive oxygen species, improved the electron transport and photosynthesis rate under cold stress applied at the jointing stage, whereas mechano-stimulation applied 6 days before the cold event induced an opposite effect, except for APX activity and ATPase activities in chloroplasts. Proteomic and transcriptional analysis revealed that the oxidative stress 
defense, ATP synthesis, and photosynthesis-related proteins and genes are up-regulated by the mechanostimulation, which were involved in the responses of wheat plants to the cold stress.

\section{Additional file}

Additional file 1: Figure S1. Temperature difference between low temperature treatment and the normal temperature control during the cold stress treatment at jointing. (DOCX $1175 \mathrm{~kb}$ )

\section{Abbreviations}

ABA: Abscisic acid; APX: Ascorbate peroxidase; AsA: Ascorbate; ATP: Adenosine triphosphate; BSA: Bovine serum albumin; CAT: Catalase; CC: the normal temperature control; $\mathrm{CL}$ : The cold stress at jointing without early mechano-stimulation; DHAR: Dehydroascorbate reductase; DTT: Dithiothreitol; EGTA: Ethylene glycol tetraacetic acid; GPX: Glutathione peroxidase; GR: Glutathione reductase; GSR: General stress response; HEPES: 4-(2-hydroxyethyl)-1-piperazineethanesulfonic acid; H2O2: Hydrogen peroxide; IEF: Isoelectrofocusing; JA: Jasmonic acid; LEA-related COR protein: Late embryogenesis abundant protein-related cold-responsive protein; MOPS: 3-(N-morpholino) propanesulfonic acid; MS: Mass spectrometry; NADPH: Nicotinamide adenine dinucleotide phosphate; NBT: Nitroblue tetrazolium; $\mathrm{O}_{2}$ : Singlet oxygen; $\mathrm{P}_{1} \mathrm{~L}$ : The combined treatment of early priming of mechano-stimulation at the Zadoks growth stage 26 and a 4-day cold event at the jointing stage; $P_{2} L$ : The combined treatment of the later mechano-stimulation 6 days before the cold event and a 4-day cold event at the jointing stage; PMSF: Phenylmethylsulphonyl fluoride; PSII: Photosystem II; PVP: Polyvinylpyrro-lidone; ROS: Reactive oxygen species; RSR: Rapid stress response; RWR: Rapid wound response; SDS: Sodium dodecyl sulfate; SOD: Superoxide dismutase; SRM: Sorbitol resuspension medium; TCA: Trichloroacetic acid.

\section{Competing interests}

The authors declare that they have no competing interests.

\section{Authors' contributions}

D.J., Q.Z. and J.C. conceived the idea and led the study design. X.L., C.H. and J.Z. carried out the experiment, performed analyses and wrote the paper. F.L., T.D. and W.C. assisted with study design, data analysis, and writing. All authors contributed to the editing of the manuscript. All authors have read and approved the final version of the manuscript.

\section{Acknowledgments}

This study is supported by projects of PAPD, the National Natural Science Foundation for Distinguished Young Scientists (31325020), the National Natural Science Foundation of China $(31171484,31471445)$, the Specialized Research Fund for the Doctoral Program of Higher Education (20090097110009), the National Non-profit Program by Ministry of Agriculture (200903003), and the China Agriculture Research System (CARS-03).

\section{Author details \\ 'National Engineering and Technology Center for Information Agriculture / Key Laboratory of Crop Physiology and Ecology in Southern China, Ministry of Agriculture, Nanjing Agricultural University, Nanjing 210095, China. ${ }^{2}$ Faculty of Science, Department of Plant and Environmental Sciences, University of Copenhagen, Højbakkegaard Allé 13, DK-2630 Taastrup, Denmark.}

Received: 24 June 2015 Accepted: 9 September 2015

Published online: 11 September 2015

\section{References}

1. Ruelland E, Vaultier MN, Zachowski A, Hurry V. Cold signalling and cold acclimation in plants. In: Jean-Claude K, Delseny M, editors. Advances in Botanical Research. Amsterdam: Elsvier Science B.V; 2009. p. 35-150.
2. Chen S, Yin C, Strasser RJ, Govindjee, Yang C, Qiang S. Reactive oxygen species from chloroplasts contribute to 3-acetyl-5-isopropyltetramic acid-induced leaf necrosis of Arabidopsis thaliana. Plant Physiol Bioch. 2012;52:38-51.

3. Rinalducci S, Egidi MG, Karimzadeh G, Jazii FR, Zolla L. Proteomic analysis of a spring wheat cultivar in response to prolonged cold stress. Electrophoresis. 2011;32:1807-18.

4. Han Q, Kang G, Guo T. Proteomic analysis of spring freeze-stress responsive proteins in leaves of bread wheat (Triticum aestivum L.). Plant Physiol Bioch. 2013;63:236-44.

5. Shimmen T. Electrical perception of "death message" in Chara: Involvement of turgor pressure. Plant Cell Physiol. 2001;42:366-73.

6. Engelberth J, Contreras CF, Viswanathan S. Transcriptional analysis of distant signaling induced by insect elicitors and mechanical wounding in Zea mays. PLOS ONE. 2012;7:e34855.

7. Jaffe M, Forbes $\mathrm{S}$. Thigmomorphogenesis: the effect of mechanical perturbation on plants. Plant Growth Regul. 1993;12:313-24.

8. Keller E, Steffen KL. Increased chilling tolerance and altered carbon metabolism in tomato leaves following application of mechanical stress. Physiol Plantarum. 1995;93:519-25.

9. Walley JW, Coughlan S, Hudson ME, Covington MF, Kaspi R, Gopalan B, et al. Mechanical stress induces biotic and abiotic stress responses via a novel ciselement. PLoS Genet. 2007;3:e172.

10. Vorwerk S, Somerville $S$, Somerville C. The role of plant cell wall polysaccharide composition in disease resistance. Trends Plant Sci. 2004;9:203-9.

11. Orozco-Cardenas M, Ryan CA. Hydrogen peroxide is generated systemically in plant leaves by wounding and systemin via the octadecanoid pathway. P Natl Acad Sci USA. 1999;96:6553-7.

12. Ślesak I, Ślesak H, Libik M, Miszalski Z. Antioxidant response system in the short-term post-wounding effect in Mesembryanthemum crystallinum leaves. J Plant Physiol. 2008;165:127-37.

13. León J, Rojo E, Sánchez-Serrano JJ. Wound signalling in plants. J Exp Bot. 2001;52:1-9.

14. Chang C, Ball L, Fryer MJ, Baker NR, Karpinski S, Mullineaux PM. Induction of ASCORBATE PEROXIDASE 2 expression in wounded Arabidopsis leaves does not involve known wound-signalling pathways but is associated with changes in photosynthesis. Plant J. 2004;38:499-511.

15. Suzuki N, Mittler R. Reactive oxygen species-dependent wound responses in animals and plants. Free Radical Bio Med. 2012;53:2269-76.

16. Li X, Cai J, Liu F, Dai T, Cao W, Jiang D. Cold priming drives the sub-cellular antioxidant systems to protect photosynthetic electron transport against subsequent low temperature stress in winter wheat. Plant Physiol Biochem. 2014:82:34-43.

17. Strasser R, Tsimilli-Michael M, Srivastava A. Analysis of the chlorophyll a fluorescence transient. In: Papageorgiou GC, Govindjee, editors. Chlorophyll Fluorescence: A Signature of Photosynthesis. Dordrecht: Springer; 2004. p. 321-62.

18. Zheng C, Jiang D, Liu F, Dai T, Jing Q, Cao W. Effects of salt and waterlogging stresses and their combination on leaf photosynthesis, chloroplast ATP synthesis, and antioxidant capacity in wheat. Plant Sci. 2009;176:575-82

19. Tan W, Liu J, Dai T, Jing Q, Cao W, Jiang D. Alterations in photosynthesis and antioxidant enzyme activity in winter wheat subjected to post-anthesis water-logging. Photosynthetica. 2008;46:21-7.

20. Miyake C, Asada K. Thylakoid-bound ascorbate peroxidase in spinach chloroplasts and photoreduction of its primary oxidation product monodehydroascorbate radicals in thylakoids. Plant Cell Physiol. 1992:33:541-53.

21. Pérez P, Alonso A, Zita G, Morcuende R, Martínez-Carrasco R. Downregulation of Rubisco activity under combined increases of $\mathrm{CO}_{2}$ and temperature minimized by changes in Rubisco kcat in wheat. Plant Growth Regul. 2011;65:439-47.

22. Ding C, You J, Liu Z, Rehmani MIA, Wang S, Li G, et al. Proteomic analysis of low nitrogen stress-responsive proteins in roots of rice. Plant Mol Biol Rep. 2011;29:618-25.

23. Baek KH, Skinner DZ. Alteration of antioxidant enzyme gene expression during cold acclimation of near-isogenic wheat lines. Plant Sci. 2003;165:1221-7.

24. Livak KJ, Schmittgen TD. Analysis of relative gene expression data using real-time quantitative PCR and the 2(-Delta Delta C(T)) Method. Methods. 2001;25:402-8

25. Minibayeva F, Kolesnikov O, Chasov A, Beckett RP, Lüthje S, Vylegzhanina N, et al. Wound-induced apoplastic peroxidase activities: their roles in the 
production and detoxification of reactive oxygen species. Plant Cell Environ. 2009;32:497-508

26. Soares NC, Wojtkowska J, Jackson PA. A proteomic analysis of the wound response in Medicago leaves reveals the early activation of a ROS-sensitive signal pathway. J Proteomics. 2011;74:1411-20.

27. Asada K. The water-water cycle in chloroplasts: scavenging of active oxygens and dissipation of excess photons. Ann Rev Plant Biol. 1999;50:601-39.

28. Keunen E, Peshev D, Vangronsveld J, Van den Ende W, Cuypers A. Plant sugars are crucial players in the oxidative challenge during abiotic stress: Extending the traditional concept. Plant Cell Environ. 2013;36:1242-55.

29. Wang $X$, Wollenweber B, Jacobsen $S$, Liu F, Jiang D. Pre-anthesis hightemperature acclimation alleviates damage to the flag leaf caused by post-anthesis heat stress in wheat. J Plant Physiol. 2011;168:585-93.

30. Munné-Bosch S, Alegre L. Changes in carotenoids, tocopherols and diterpenes during drought and recovery, and the biological significance of chlorophyll loss in Rosmarinus officinalis plants. Planta. 2000;210:925-31.

31. Bohnert HJ. What makes desiccation tolerable? Genome Biol. 2000;1:1-4.

32. Janska AA, Marsik P, Zelenkova S, Ovesna J. Cold stress and acclimation - what is important for metabolic adjustment? Plant Biol. 2010;12:395-405.

33. Kang G, Li G, Xu W, Pen X, Han Q, Zhu Y, et al. Proteomics reveals the effects ofsalicylic acid on growth and tolerance to subsequent drought stress in wheat. J Proteome Res. 2012;11:6066-79.

34. Chehab EW, Eich E, Braam J. Thigmomorphogenesis: a complex plant response to mechano-stimulation. J Exp Bot. 2009;60:43-56.

35. Ma W, Smigel A, Tsai Y, Braam J, Berkowitz GA. Innate immunity signaling: cytosolic $\mathrm{Ca}^{2+}$ elevation is linked to downstream nitric oxide generation through the action of calmodulin or a calmodulin-like protein. Plant Physiol. 2008; 148:818-28

36. Walley JW, Coughlan S, Hudson ME, Covington MF, Kaspi R, Banu G, et al. Mechanical stress induces biotic and abiotic stress responses via a novel cis-element. PLoS Genet. 2007;3:e172.

37. Ye Z, Robakowski P, Suggett D. A mechanistic model for the light response of photosynthetic electron transport rate based on light harvesting properties of photosynthetic pigment molecules. Planta. 2013;237:837-47.

38. Yusuf MA, Kumara D, Rajwanshia R, Strasserb RJ, Tsimilli-Michaelb M, Govindjee $X$, et al. Overexpression of $\gamma$-tocopherol methyl transferase gene in transgenic Brassica juncea plants alleviates abiotic stress: Physiological and chlorophyll a fluorescence measurements. BBA Bioenergetics. 2010;1797:1428-38

39. Chen S, Zhou F, Yin C, Strasser R, Yang C, Qiang S. Application of fast chlorophyll a fluorescence kinetics to probe action target of 3-acetyl-5-isopropyltetramic acid. Environ Exp Bot. 2011;73:31-41.

\section{Submit your next manuscript to BioMed Central and take full advantage of:}

- Convenient online submission

- Thorough peer review

- No space constraints or color figure charges

- Immediate publication on acceptance

- Inclusion in PubMed, CAS, Scopus and Google Scholar

- Research which is freely available for redistribution 